\title{
ЭЛЕКТРОННАЯ ПОДПИСЬ В УГОЛОВНОМ ПРОЦЕССЕ РОССИИ
}

Аннотация: в настоящей статье рассмотрены современные тенденции вовлечения информационных технологий в уголовный процесс Российской Федерации. Сделаны предложения по изменению законодательства в целях оптимизации раскрытия и расследования преступлений. Автором обращено внимание на отсутствие однозначных критериев использования электронных документов в качестве доказательств, что приводит к назначению компьютерно-технических экспертиз в целях определения подлинности документов. Также в уголовно-процессуальном законодательстве отсутствует регламентация использования прочессуальных документов, составленных в электронной форме. Автором проанализированы предложения ряда авторов о проведении отдельных следственных действий в электронной форме. Констатируется отсутствие нормативных положений в Уголовно-процессуальном кодексе Российской Федерации, позволяющих использовать усиленную квалифицированную подпись для разрешения вышеперечисленных вопросов. Приведены и проанализированы примеры из следственной и судебной практики использования электронных документов в уголовном процессе, на основании которых предложены отдельные критерии использования электронных документов.

Ключевые слова: электронная подпись, процессуальные документы, электронная форма документа, электронный документ, материальные носители информации, расследование преступлений, сообщение о преступлении, доказательство, обвинительное заключение, копирование информации.

DOI: $10.7256 / 1994-1471.2014 .6 .10292$

$\Pi$ оявление новых способов передачи, хранения и представления информации отражает объективно существующие тенденции развития общественных отношений. В зарубежных исследованиях активно развивается научное направление «визуализация права» ${ }^{1}$, в котором анализируется влияние изменения форм коммуникации на правоотношения.

Разнообразие ситуаций вовлечения компьютерной информации в уголовные правоотношения обусловило пристальное внимание исследователей. В настоящее время компьютерная информация может быть вовлечена в уголовный процесс по инициативе любого его участника, как правило, в форме сведений об обстоятельствах, имеющих значение для уголовного дела, и впоследствии при наличии соответствующие условий признаваемых доказательствами. Например, следователь при производстве следственных действий, а потерпевший (обвиняемый, подсудимый и т.д.) в случае использования технических средств, в том числе для подтверждения легитимности

Чуйко Н.А. Визуализация права // Журнал российского права. - 2013. - № 5. - С. 127. документа в электронном виде посредством использования нотариальных процедур².

Кувычковым С.И. отмечается, что «признаки «электронного доказательства» и критерии их вовлечения в процесс доказывания по уголовному делу до настоящего времени отсутствуют» ${ }^{3}$. При возникновении сомнений в авторстве, целостности и неизменности компьютерной информации, а также иных ее характеристиках назначается компьютернотехническая экспертиза.

Рядом последовательно внесенных изменений в Уголовно-процессуальный кодекс Российской Федерации ${ }^{4}$ (далее - УПК РФ) разреше-

\footnotetext{
2 Основы законодательства Российской Федерации о нотариате (утв. ВС РФ 11.02.1993 № 4462-1) (ред. от 05.04.2013) // Российская газета. 1993. 13 марта.

3 Кувычков С.И. Использование в доказывании электронной информации // Юридическая наука и практика: Вестник Нижегородской академии МВД России. 2012. № 2. С. 91.

4 Федеральный закон Российской Федерации от 28.07.2012 № 143-Ф3 «О внесении изменений в Уголовно-процессуальный кодекс Российской Федерации» // Российская газета. 2012. 1 августа; Федеральный закон от 29.11.2012 № 207-Ф3 «О внесении изменений в Уголовный кодекс Российской Федерации и отдельные за-
}

(c) Халиуллин Адель Ильфатович

Научный сотрудник, Академия Генеральной прокуратуры Российской Федерации [adel@lenta.ru]

123022, Россия, г. Москва, 2-я Звенигородская ул., д. 15. 
ны основные вопросы, связанные с изъятием, копированием и хранением материальных носителей информации в электронной форме. Вместе с тем вопрос о критериях электронных доказательств в уголовном процессе до настоящего времени остается дискуссионным.

В этой связи С.В. Зуев предлагает «электронное копирование информации» ${ }^{5}$ определить в качестве самостоятельного следственного действия в УПК РФ, тем самым посредством перечисления требований к данному следственному действию установить одновременно и требуемые критерии в отношении «электронных доказательств». Дополняя данную точку зрения, отмечаем, что использование в уголовном процессе информации в электронной форме предполагает четкое определение способов удостоверения ее подлинности.

Более широкий взгляд на проблему информатизации уголовного процесса содержится в исследовании М.Н. Колосовича и О.С. Колосовича, которые рассматривают возможность осуществления в электронной форме отдельных процессуальных действий (например, подача заявления о совершенном преступлении в электронной форме и подписанного заявителем электронной подписью ${ }^{6}$ ). Основное преимущество осуществления процессуальных действий в электронной форме заключается в сокращении временного интервала между моментом совершения преступления и реакцией правоохранительных органов, что также способствует соблюдению разумной продолжительности процессуальных сроков ${ }^{7}$.

Вместе с тем предложение М.Н. Колосовича и О.С. Колосовича ранее частично реализовано в приказах МВД РФ от 01.03.2012 № $140^{8}$,

конодательные акты Российской Федерации» // Российская газета. 2012. 3 декабря.

Зуев С.В., Сутягин К.И. Электронное копирование информации как самостоятельное следственное действие // Следователь. 2003. № 4. С. 14-15.

6 Колосович М.С., Колосович О.С. // Вестник Волгоградской академии МВД России. 2011. № 18. С. 125.

Терехов А.Ю. К вопросу об основаниях выбора способа собирания доказательств в ходе досудебного производства по уголовному делу // Российское полицейское право. 2013. №2. С. 62-76; Абдулвалиев А.Ф. Предпосылки и перспективы внедрения электронной формы уголовного дела в деятельность судебных органов // Вопросы права и политики. 2013. № 5. C. $150-164$.

8 Приказ МВД России от 01.03.2012 № 140 «Об утверждении Административного регламента Министерства внутренних дел Российской Федерации о предоставления государственной услуги по приему, регистрации и разрешению в территориальных органах Министерства внутренних дел Российской Федерации заявлений, сообщений и иной информации о преступлениях, об административных правонарушениях, о происшестви-
Следственного комитета РФ от 11.10.2012 № $72^{9}$, ФСБ РФ от 16.05 .2006 № $205^{10}$, согласно которым «сообщение о происшествии может поступать в орган внутренних дел лично от заявителя, нарочным, по почте, по телефону, телеграфу, информационным системам общего пользования, факсимильным или иным видом связи». Вышеперечисленными приказами установлен порядок приема сообщений в электронной форме, поступивших по информационным системам общего пользования, а также применения программного обеспечения, предусматривающего обязательное заполнение заявителем реквизитов, необходимых для работы с сообщениями о происшествиях.

Получение сообщения о совершенном преступлении в электронной форме затрудняет обеспечение достоверного установления личности составителя документа, особенно в отношении заведомо ложных доносов.

Электронная форма является перспективной для осуществления и иных процессуальных действий. Например, реализации права прокурора по мотивированному письменному запросу ознакомиться с материалами находящегося в производстве уголовного дела (п. 2.1 ст. 37 УПК РФ) посредством получения их в электронной форме. Электронные копии документов, полученные путем сканирования бумажного носителя, приказ Генеральной прокуратуры Российской Федерации от 29.12.2011 № $450^{11}$ получили наименование «электронного образа документа». Но применение «электронного образа документа» ограничено только рамками электронного документооборота. В отношении «электронного образа документа» возникает, как и в отношении заявления о преступлении в электронной форме, проблема по обеспечению легитимности. Действенным

ях» (Зарегистрировано в Минюсте России 20.06.2012 № 24633) // Российская газета. 2012. 1 августа.

9 Приказ Следственного комитета России от 11.10.2012 № 72 «Об организации приема, регистрации и проверки сообщений о преступлении в следственных органах (следственных подразделениях) системы Следственного комитета Российской Федерации» // Российская газета. 2013. 6 марта.

10 Приказ ФСБ РФ от 16.05.2006 № 205 «Об утверждении Инструкции по организации в органах Федеральной службы безопасности приема, регистрации и проверки сообщений о преступлениях и иной информации о преступлениях и событиях, угрожающих личной и общественной безопасности» (Зарегистрировано в Минюсте РФ 09.10.2006 № 8364) // Российская газета. 2006. 20 октября.

11 Приказ Следственного Комитета России от 18.07.2012 № 40 «Об утверждении Инструкции по делопроизводству Следственного комитета Российской Федерации» // СПС КонсультантПлюс. 
способом преодоления настоящей проблемы представляется использование электронной подписи.

Существуют требования, соблюдение которых определяет равнозначность электронной подписи и подписи, выполненной собственноручно графическим способом. Высшая степень криптографической защиты усиленной квалифицированной электронной подписи обеспечивает ее признание равнозначной собственноручной подписи и оттиску печати во всех случаях, кроме прямо предусмотренных нормативными актами или соглашением сторон исключений.

К сожалению, принятие Федерального закона от 06.04.2011 № 63-ФЗ (ред. от 02.07.2013) «Об электронной подписи» ${ }^{12}$ не повлекло внесения соответствующих изменений в нормы УПК РФ. Согласно ч. 2 ст. 474 УПК РФ процессуальные документы могут быть составлены в электронной форме, но отсутствует указание на необходимость применения квалифицированной электронной подписи для удостоверения подписи участника следственного действия.

Востребованность регламентации использования электронной подписи в уголовном процессе демонстрирует процесс расследования уголовного дела в отношении С. Полонского. Последний, находясь в международном розыске по запросу Российской Федерации, обратился в следственные органы МВД России с ходатайством о заключении доследственного соглашения посредством направления электронного письма на общий адрес электронной почты МВД России. Следователем данное обращение не было принято к рассмотрению, так как «подлинность данного сообщения и способ его доставки вызвали сомнение» ${ }^{13}$. Считаем, что использование электронной подписи в подобной ситуации позволило бы однозначно подтвердить подлинность составленного ходатайства.

Другой пример, напротив, показывает, что существуют специальные условия, при соблюдении которых процессуальные документы могут быть составлены в электронной форме. Так, в постановлении Президиума Верховного суда РФ № 444П10пр указано, что «судья возвратил уголовное дело прокурору для устранения препятствий его рассмотрения судом в силу того, что тексты обвинительного заклю-

12 Федеральный закон от 06.04.2011 № 63-Ф3 (ред. от 02.07.2013) «Об электронной подписи» // Парламентская газета. 2011. 14 апреля.

Россия направила Камбодже запрос о выдаче Полонского // BBC: Русская служба новостей. URL: http:// www.bbc.co.uk/russian/russia/2013/11/131107_polonsky_ general_prosecutor.shtml. (дата обращения: 13.11.2013) чения переданы обвиняемому на электронном носителе информации. Как установлено судом, подсудимому не были вручены копии машинописного текста обвинительного заключения в полном объеме (из 84 томов вручено только лишь 8 томов), а весь текст обвинительного заключения передан на электронном носителе информации, что не предусмотрено уголовно-процессуальным законом. ... Лишь в случае письменного отказа обвиняемого от получения копии в машинописном варианте с согласия обвиняемых им могли быть вручены тексты обвинительного заключения на электронном носителе информации...» ${ }^{14}$.

В данном случае очевидно нарушение процедуры реализации права на защиту, а именно отсутствия у стороны защиты права ознакомиться в удобной для восприятия форме с материалами уголовного дела для формулирования своей позиции. В то же время Президиум Верховного Суда РФ указывает, что текст обвинительного заключения может быть передан обвиняемому на электронном носителе информации лишь после получения письменного отказа от получения машинописного текста. По нашему мнению, необходимо закрепить в УПК РФ перечень процессуальных документов, которые могут быть составлены в электронной форме. При этом в качестве условия составления процессуального документа в электронной форме может быть признаны: наличие согласия и технической возможности у заинтересованных лиц. Например, согласие всех участников следственного действия на составление его протокола в электронной форме, также наличие технической возможности использовать квалифицированную электронную подпись всеми участниками следственного действия.

На основании изложенного нами предложены следующие направления совершенствования уголовно-процессуального законодательства:

- закрепить в качестве обязательного критерия для процессуальных документов, выполненных в электронной форме, использование усиленной квалифицированной подписи;

- определить в качестве условия составления процессуальных документов в электронной форме согласие на то заинтересованных лиц (например участников следственного действия) и наличие у них технической возможности использовать квалифицированную электронную подпись;

14 Обзор судебной практики Верховного Суда Российской Федерации за второй квартал 2011 года (утв. Президиумом Верховного Суда РФ 28.09.2011) // Бюллетень Верховного Суда РФ. № 11. 2011. 
- разработать процедуры осуществления электронного документооборота, в том числе создание юридически равноценных копий на бумаге с отображением электронной подписи для процессуальных документов, изначально созданных в электронной форме (например, распечатка фрагмента откры- того кода электронной подписи в качестве приложения к электронному документу, переводимого в машинописную форму);

- регламентировать последовательность проверки подлинности электронной подписи в процессуальном документе, в том числе и по ходатайству стороны защиты.

\section{Библиография:}

1. Чуйко Н.А. Визуализация права // Журнал российского права. - 2013. - № 5. - С. 121-131.

2. Кувычков С.И. Использование в доказывании электронной информации // Юридическая наука и практика: Вестник Нижегородской академии МВД России. - Нижний Новгород: Изд-во Нижегор. акад. МВД России, 2012, № 2. - С. 90-92.

3. Зуев С.В., Сутягин К.И. Электронное копирование информации как самостоятельное следственное действие // Следователь. 2003. - № 4. С. 14-15.

4. Колосович М.С., Колосович О.С. Электронная форма заявления как повод для возбуждения уголовного дела // Вестник Волгоградской академии МВД России. - Волгоград: Изд-во Волгогр. акад. МВД России, 2011, № 3 (18). - С. 124-130.

5. Терехов А.Ю. К вопросу об основаниях выбора способа собирания доказательств в ходе досудебного производства по уголовному делу // Российское полицейское право. - 2013. № 2. - С. 62-76.

6. Абдулвалиев А.Ф. Предпосылки и перспективы внедрения электронной формы уголовного дела в деятельность судебных органов // Вопросы права и политики. - 2013. - № 5. C. $150-164$.

7. Халиуллин А.И. Внедрение электронного документооборота в деятельность правоохранительных органов государств Содружества Независимых Государств // Кибернетика и программирование. - 2013. - 6. - С. 12-16.

\section{References:}

1. Chuiko N.A. Vizualizatsiya prava // Zhurnal rossiiskogo prava. - 2013. - № 5. - S. 121-131.

2. Kuvychkov S.I. Ispol'zovanie $\mathrm{v}$ dokazyvanii elektronnoi informatsii // Yuridicheskaya nauka i praktika: Vestnik Nizhegorodskoi akademii MVD Rossii. - Nizhnii Novgorod: Izd-vo Nizhegor. akad. MVD Rossii, 2012, № 2. - S. 90-92.

3. Zuev S.V., Sutyagin K.I. Elektronnoe kopirovanie informatsii kak samostoyatel'noe sledstvennoe deistvie // Sledovatel'. 2003. - № 4. S. 14-15.

4. Kolosovich M.S., Kolosovich O.S. Elektronnaya forma zayavleniya kak povod dlya vozbuzhdeniya ugolovnogo dela // Vestnik Volgogradskoi akademii MVD Rossii. - Volgograd: Izd-vo Volgogr. akad. MVD Rossii, 2011, № 3 (18). - S. 124-130.

5. Terekhov A.Yu. K voprosu ob osnovaniyakh vybora sposoba sobiraniya dokazatel'stv v khode dosudebnogo proizvodstva po ugolovnomu delu // Rossiiskoe politseiskoe pravo. - 2013. - № 2. C. 62-76.

6. Abdulvaliev A.F. Predposylki i perspektivy vnedreniya elektronnoi formy ugolovnogo dela v deyatel'nost' sudebnykh organov // Voprosy prava i politiki. - 2013. - № 5. - C. 150-164.

7. Khaliullin A.I. Vnedrenie elektronnogo dokumentooborota $v$ deyatel'nost' pravookhranitel'nykh organov gosudarstv Sodruzhestva Nezavisimykh Gosudarstv // Kibernetika i programmirovanie. 2013. - 6. - C. 12-16. 